\title{
Sustainable Forest Management in North-East Asia: A Comparative Assessment between China and Republic of Korea
}

\section{Youngsu Park1 ${ }^{1}$, Yujun Sun ${ }^{1}$}

\author{
${ }^{1}$ State Forestry Administration Key Laboratory of Forest Resources and Environmental Management, Beijing \\ Forestry University, Beijing 100083, China
}

\begin{abstract}
The extent of the forest resource in the Northeast Asian region is vast. Characterized by temperate and boreal forests and covering about $28 \%$ of the world's forested area, the importance of the region's forest resource in terms of its contribution to the global carbon cycle and maintenance of biological diversity cannot be overstated. In recent years, land use and land cover, particularly forest cover, in the region has changed significantly. Driven by wars, population growth and economic development, forests have on one hand been on the decline, but on the other hand were restored and rehabilitated at a pace and scale unimaginable in other parts of the world. Republic of Korea (South Korea) and China, both countries with vast amount of forests, serve typical case of progressive forest cover decline during socio-political transition followed by restoration and rehabilitation during period of stable reform. Nationwide forest restoration and rehabilitation projects was implemented in both China and Korea during 1970s and 1980s in order to restore degraded forests and further provide invaluable forest-related goods and services. In recent times, both countries have experienced a pronounced increase in forest area and density. However, the pace and the current directions are very different for both countries. While Korea has already achieved absolute reversal of deforestation and has begun to focus on enhancing ecosystem and economic benefits from forests, China, in part due to its vast and diverse forest landscape, is still struggling with preventing forest cover loss and meeting socioeconomic needs of rural forest dependent people through series of tenure reform processes. The forest governance in both countries are also starkly different, that has shaped both pace and direction of sustainable forest management. In this context, this paper uses an analysis of literature from secondary sources to compare and contrast the past and present achievements in both countries, in order to find pragmatic solutions towards sustainable forest management and rehabilitation that would prove useful in pragmatic policy and decision making in developing countries across the Asia-Pacific region.
\end{abstract}

Keywords: Sustainable Forest Management, Forest Transition, Rehabilitation, South Korea, China

\begin{abstract}
Introduction
The world is facing rapid expansion of population and increasing demands for forest products and services (Lee \& Lee, 2005). Sustainable forest management (SFM) has been emphasized since the Rio de Janeiro Summit held in 1992. However, the concept of sustainability in forestry sector is much older and gradually developed from the concept of sustained yield, which refers only to the forest's productive function, towards the concept of SFM, which includes ecological, social and economic aspects as well (Holvoet \& Muys, 2004). After the Rio Summit, where international forest principles were formulated for the first time, the notion of SFM rapidly gained interest. It entails the balancing of the economic, environmental and social functions, and values of forests for the benefit of present and future generations (FAO, 2000). Forest sustainability is
\end{abstract}

needed especially in the developing countries since they make up $80 \%$ of the world's population and their tropical forests have been degraded by about 1 million ha $\mathrm{yr}^{-1}$ (Lee \& Lee, 2005).

The extent of the forest resource in the northeast Asian region is vast. This region, characterized by temperate and boreal forests, contains about $28 \%$ of the world's forested area (Moon \& Park, 2004). The importance of the region's forest resource is also represented by its significant contribution to the global carbon cycle and maintenance of biological diversity. However, ongoing degradation of the forest ecosystems in this region shows little sign of decreasing. Although the total extent of forest in the northern temperate and boreal regions has not changed much in recent years, in many areas the species-rich and old growth forests have been

This article is published under the terms of the Creative Commons Attribution License 4.0

Author(s) retain the copyright of this article. Publication rights with Alkhaer Publications.

Published at: http://www.ijsciences.com/pub/issue/2018-04/

DOI: 10.18483/ijSci.1645; Online ISSN: 2305-3925; Print ISSN: 2410-4477 
steadily replaced by the second-growth forests and plantations (Moon \& Park, 2004).

Over the last century, land use in the Northeast Asian region has changed significantly. This is also true for the management and conservation of the region's vast forest resources. Driven by wars, population growth and economic development, forests have on one hand been on the decline, but on the other hand were restored and rehabilitated at a pace and scale unimaginable in other parts of the world (Kleine \& Lee, 2007). Today, the extent of forest cover in Northeast Asia varies considerably between countries and sub-regions. This is not only due to natural conditions shaped by climate, elevation and topography, but to a large extent also influenced over the centuries by human activities. Countries with presently high forest cover such as China and the Republic of Korea are endowed with natural conditions favouring tree growth, thus making forests the main natural vegetation type. However, after a long history of forest clearing and destruction caused by intensive use of wood as fuel, agriculture expansion and war-time activities (only in the last 50 to 60 years) both countries are in way to restoring their forest cover through significant efforts by governments and society (Kleine \& Lee, 2007).

China, the second largest country in Northeast Asia after Russia, has experienced deforestation and forest degradation over many centuries. Early agricultural civilization, rapid population growth, numerous wars and migration events, and irrational forest resources development have contributed to forest degradation. In 1949, only about 9\% of China's total land area was covered with forests and trees. For example, the major natural forests in the Northeast, the Southwest, and the Southeast had gone through a period of rapid degradation from 1700 to 1949 with significant decline in forest cover. Large-scale afforestation efforts between 1949 and today have significantly expanded the forest area and resulted in a total forest cover of about $18 \%$. Because of these massive reforestation activities China's forest ecosystems are today dominated by young stands with profound implications for their ecological function and sustainable management (Kleine \& Lee, 2007).

Similar to China, the Korean peninsula experienced severe deforestation and forest degradation after the Korean War (1950-1953). Food and energy demands led to the conversion of forestlands into agricultural lands and the excessive exploitation of forest resources. South Korea and North Korea have established and implemented reforestation policies respectively. South Korea achieved forest recovery in the 1970s (Bae, Joo, \& Kim, 2012). South Korea's successful reforestation experience is considered a good model for developing countries (Noronha, 1981). Its reforestation is regarded as a result of the South Korean government's policy intervention (M. Park \& Youn, 2013). In particular, the National Greening Program contributed to successful reforestation in South Korea for two decades (Bae et al., 2012). Given the fact that the Republic of Korea has largely achieved its targets of reforestation and forest rehabilitation, the major focus of the current National Forest Plan is to build forest management policies addressing the diverse socio-economic needs with due consideration and guidance by international trends and policies. Several laws and regulations related to erosion control, forestry cooperatives, promotion of forestry and mountain villages, promotion of forest arboretum, and the Forest Land Management Act have been amended over the years and positively contributed to rebuilding forest resources in this country (Kleine \& Lee, 2007).

The policy move of the above two countries towards greater local control is reflected in a wide range of community-based arrangements, such as participatory, joint or collaborative forest management. Although local community institutions can be effective in governing their forest resources, weak community institutions also do not get stronger by the devolution of authority. The lacking capacity to absorb additional requirements from decentralization can be difficult and potentially dangerous (Barrow \& Murphree, 2001). The challenge for research and policy is therefore; to systematically identify an institutional environment which delivers benefits to local people and simultaneously sustains natural resources. To master this challenge, it is of prime importance to understand the role of property rights and the implications of certain rule arrangements for particular groups (e.g. woman, the marginalized). No single property regime is best for sustaining local livelihoods and natural resources (Dietz, Ostrom, \& Stern, 2003). Equally significant are secure rights over the use of natural resources. Insecurity undermines the incentive to engage in long-lasting sustainable resource management practices (Arrow, 1996). Knowledge of the complexity and diversity of institutions in a decentralized governance situation is therefore crucial to the livelihoods, especially of rural populations in North-East Asia and to sustainable natural resource management, which again can be a driver for overall economic development. This article aims to compare and contrast the various efforts and current achievements towards sustainable forestry management in North-East Asia, taking Republic of Korea (South Korea hereafter) and China as the case study. The outcomes will be helpful in designing 
pragmatic sustainable forest resources management, not only in Korea and China, but also the entire regions of North-East Asia.

\section{Methodology}

The article compares between two countries: (a) South Korea, and (b) China, located in North-East part of Asia (Figure 1), and is primarily based on the collection and analysis of data from the secondary source. This included scientific papers, project reports, technical reports, books, book chapters, and relevant websites among others. Using the Web of Science $^{\mathrm{TM}}$ database and a special string of keywords, the relevant literature were identified, and analyzed.

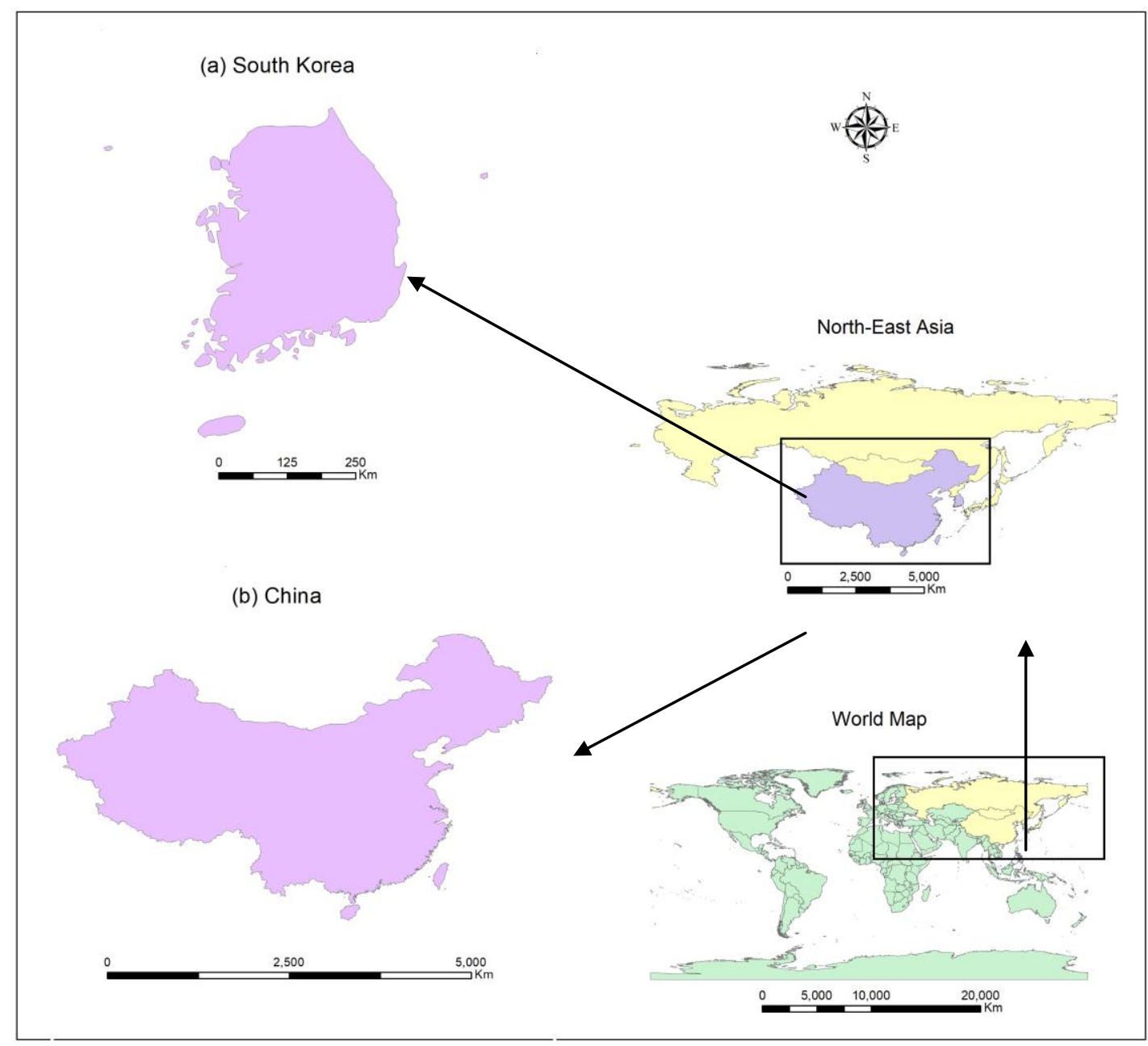

Figure 1: Location map of (a) South Korea and (b) China in North-East Asia

\section{Findings and Discussion}

\subsection{Status and Changes of Forest Cover}

\subsubsection{South Korea}

Changes in the stocked forest area of South Korea can be characterized by four stages: Expansion Period (1927-1942), Reduction Period (1943-1955), Re-expansion Period (1956-1980), and Stabilization Period (1981-2007). Non-stocked forestland area dramatically decreased from 3.3 million ha in 1955 to 170,000 ha in 2007. In the same period, the stocked forest area nearly doubled to 6.2 million ha. From the trend changes in non-stocked and stocked forest lands, we see clear evidence of forest recovery or forest transition. Indeed, from 1952 to 1968 , some non-stocked forests were converted to agricultural lands, resulting in increased agricultural land from 1.97 million ha to 2.34 million ha. In the 1970 s, some forest lands were converted to agricultural lands and then converted to residential, industrial and other uses, which explains the later decline of agricultural lands continuing until 2007. In the meantime, the average volume of growing stock changed in three stages: Reduction Period (1927-1952); Stagnation Period (1953-1972), and Expansion Period (19732007). The Reduction Period was a time of forest degradation when both per-hectare growing stock and per-capita growing stock continued to decrease. Late in the period, the annual growing stock per capita 
decreased by $2.9 \%$ due to the rapid population increase in South Korea after the World War II. During the Stagnation Period, there was no change in both per-hectare and per-capita growing stocks. From 1973 to 2007, both per-hectare and per-capita growing stocks increased by $20.0 \%$ and $14.4 \%$, respectively, completely reversing the trend of the previous period. Indeed, the average volume of growing stock in stocked forests increased from 10.5 $\mathrm{m} 3 / \mathrm{ha}$ in 1952 to $100.4 \mathrm{~m}^{3} / \mathrm{ha}$ in 2007 . Despite the steady increase in population following World War II, the volume of growing stock per capita increased by 7.4 times during the same period (from $1.7 \mathrm{~m}^{3}$ to $12.9 \mathrm{~m}^{3}$ ). In particular, the massive migration of rural, wood- burning populations into cities had a positive effect on the forest rehabilitation in South Korea (Lee \& Lee, 2005). Forest area and growing stock from 1960 to 2000 are given in Table 1 .

Table 1. Forestland area and growing stock by year in South Korea

\begin{tabular}{cccc}
\hline Year & Area $\left(\mathbf{1 0}^{\mathbf{3}} \mathbf{h a}\right)$ & Growing stock $\left.\mathbf{( 1 0}^{\mathbf{3}} \mathbf{~ m}^{\mathbf{3}}\right)$ & Growing stock $\left(\mathbf{m}^{\mathbf{3}} \mathbf{h a}\right)$ \\
\hline 1960 & 6,700 & 63,995 & 9.55 \\
1970 & 6,611 & 68,772 & 10.40 \\
1980 & 6,567 & 145,694 & 22.18 \\
1990 & 6,476 & 248,426 & 38.36 \\
2000 & 6,430 & 387,758 & 60.30 \\
\hline
\end{tabular}

Source: (Lee \& Lee, 2005)

\subsubsection{China}

Over the past decades, forest area and growing stock density in China increased at the annual rates of $0.51 \%$ and $0.44 \%$, respectively. Afforestation or reforestation has occurred in $73.3 \%$ (22 out of 30 ) of China's provinces and that $16.7 \%$ (5 out of 30 ) experienced rapid forest expansion (an annual increase of $.2 .0 \%$ ). Overall, the forest growing stock increased in 27 provinces, of which 16 showed increases in both area and density, six showed increases in forest area but decreases in density (i.e., Yunnan, Hainan, Jiangxi, Sichuan, Guizhou and Shanxi), and five increased in density but decreased in forest area (Jilin, Shaanxi, Inner Mongolia, Xizang and Shandong). As a result, $43.8 \mathrm{Tg}$ carbon was sequestered annually by China's forests. Overall forest expansion and growth over the past several decades and the resulting carbon uptake by China's forests have also been observed in previous studies (Fang et al., 2001; Piao et al., 2009). These increases are primarily attributed to several national reforestation and afforestation programs implemented since the 1980s (such as the River Protection Forest Project, the Natural Forest Protection Program and the Conversion of Cropland to Forest Program) (Carle, Vuorinen, \& Del Lungo, 2002). Despite an overall increase in both area and density for China's forests, declines in forest area and/or growth occurred in some regions. For example, eight provinces (Ningxia, Gansu, Xizang, Jilin, Heilongjiang, Shaanxi, Inner Mongolia and Shandong) experienced a forest shrinkage, and eight provinces (Hainan, Jiangxi, Sichuan, Yunnan, Guizhou, Ningxia, Shanxi and Heilongjiang) underwent a decline in forest density. Evidently, most of the provinces with shrinking forest are located in the arid region. Those with declining forest density are mainly in the Southwest China, where the average forest stock density is relatively high. Forest area and growing stock from 1981 to 2003 are given in Table 1 .

Table 1. Forestland area and growing stock by year in China

\begin{tabular}{cccc}
\hline Year & Area $\left(\mathbf{1 0}^{\mathbf{3}} \mathbf{h a}\right)$ & Growing stock $\left.\mathbf{( 1 0}^{\mathbf{4}} \mathbf{m}^{\mathbf{3}}\right)$ & Growing stock $\left(\mathbf{m}^{3} / \mathbf{h a}\right)$ \\
\hline 1981 & 12,300 & 889,167 & 77.29 \\
1988 & 13,127 & 963,259 & 73.38 \\
1993 & 13,926 & $1,070,491$ & 76.87 \\
1998 & 12,919 & $1,008,457$ & 78.06 \\
2003 & 14,280 & $1,209,944$ & 84.73 \\
\hline
\end{tabular}




\subsection{Evolution of Policies towards Sustainable Forest Management}

\subsubsection{South Korea}

After the Korean War, an increasing population boosted food and energy demands, which in turn led to the conversion of forestlands into agricultural lands and the excessive exploitation of fuel wood for energy. The South Korean government implemented a forest protection policy to decrease deforestation. The Forest Product Control Act of 1961 regulated gathering and extracting products in the mountains. The Abolishment of Slash-and-Burn Fields Act of 1966 prohibited slash-and-burn cultivation. However, it was not completely abolished until 1970s. Despite the introduction of the forest protection policy, illegal logging was not controlled. From 1945 to 1961 , the frequency of illegal logging was 24,085 cases, and the average volume of illegally logged timber was 92,853 $\mathrm{m}^{3}$ per year (Kim et al., 2009). Recognizing importance of forest rehabilitation and strengthening forest policies, the Forestry Bureau under the Ministry of Agriculture and Forestry (MAF) had to be expanded for effective and efficient forest policy. To strengthen forest administration power, the Korea Forest Service (KFS) was created as a national forest administration agency under the MAF in 1967.

To restore these devastated forests that had caused serious social problems (e.g., lack of fuel, severe floods and droughts), the National Forest Development Plans (NFDPs) were established. After legal and institutional preparations in the 1960s, the Forest Rehabilitation Projects were initiated in 1973. During the 1st NFDP, from 1973 to 1978, erosion control works were conducted in a total 41,932 ha. The government declared the Nationwide Tree planting period (21 March-20 April) and Arbour Day to encourage active public participation. The 2nd 10year NFDP (1979-1987) aimed to establish largescale commercial forests that could be developed into sustainable timber resources for domestic timber demands. The government implemented various forest policies such as forest rehabilitation, forest protection enhancement, and the foundation of forest development funds to support private and national forests. Along with reforestation projects, erosion control was also actively undertaken to prevent natural disasters. Advanced biotechnology was also adopted to control forest diseases and pests. Under the $2^{\text {nd }}$ NFDP, 1.06 million ha of forests were established. Based on forest resources, the $3^{\text {rd }}$ NFDP (1988-1997) aimed to harmonize the economic functions and public benefits of forests. The plan focused on establishing forest management infrastructure (e.g., forest road construction, forest mechanization, and education for foresters and forestry workers). Shifting its focus towards the economic functions of forests, this plan embodied a transitional phase in South Korean forest policy (M. S. Park \& Youn, 2013).

The third phase of South Korean forest policy was oriented toward SFM. At the global level, SFM emerged as a paradigm of forest management. South Korean forest policies reflected this global trend. The $4^{\text {th }}$ NFDP (1998-2007) entered a transitional phase in forest policy, shifting its primary focus from economic functions to enhancing multiple benefits of forests (e.g., public and recreational benefits). The $5^{\text {th }}$ NFDP (2008-2017) aims to realize a nation based on sustainable forests. Sustainable management of the forests covering $64 \%$ of total land area is crucial to realize a green nation. The plan includes five key strategies (Lee et al., 2010): (1) integrated management and development of multi-functional forest resources; (2) forest industry promotion for the sustainable use of forest resources; (3) conservation and management of forests as national environmental resources; (4) increasing green areas and services for the public; and (5) international cooperation for global forest conservation and timber supply. In accordance with the SFM paradigm to maximize multi-functional forest resources, urban forest policies have been introduced in South Korea since the late 1990s. In accordance with the Creation and Management of Forest Resources Act of 2005, the KFS established a basic plan for urban forests (20082017) in 2007. Following the plan, central and local governments are constructing and managing various types of urban forests (e.g., street trees, urban parks and school forests) (Koo, Park, \& Youn, 2013). As of 2011, a total of 10.8 million seedlings have been planted, and 957 school forests have been created.

\subsubsection{China}

Since the founding of the People's Republic of China in 1949, the Chinese Government has given priority to tree planting and forest conservation aiming at improvement of timber supplies and ecological rehabilitation. From 1950s to 1970 s, the prevalent policy on forests emphasized silviculture and sustained yielding, and "timber" was basis of most policy-making. During 1980s the forest policy has changed to emphasize "four transformation" as:

- $\quad$ shifting from previous utilization of natural forests to silvicultural treatment aiming at cultivating high quality plantations;

- $\quad$ shifting from merely timber production to diversified management and integrated 
utilization in an effort to readjust the composition of the forestry industry;

- shifting from an extensive management to an intensive management based on scientific achievements;

- $\quad$ shifting from forest managed only by forestry sector to a multi- sector forestry by promoting initiatives of the whole society for forestry development.

Under the above strategies and policy principles, China conducts the "Mass afforestation Campaign" and several huge programs of afforestation across all parts of the country. In December of 1981, the Congress adopted "the Resolution on Carrying out the National Compulsory Tree Planting Campaign" aiming at stipulating that citizens are obligated to plant 3-5 trees every year, or devote equivalent amount of effort related afforestation activities. The campaign had over 20 billion tree planted and helped arouse the public awareness of the forest and environment. In 1988, the government decided to establish 20 million ha of timber plantation over 30 years so as to relief the national forest from the pressure of the timber consumption needed its economic prosperity. At present, the total area of this kind of plantation called as "fast-growing and highyielding plantation" reached over 3.5 million ha (Xiaoping, 1998).

Over the past 20 years, forest policy also paid a great attention to the management and conservation both state-owned and collective forests. The government has conduct reforms of the ownership and managing right of the forest resources. It issued contracts to the rural residents for responsibility of land afforestation, made a series of code of forests management, conduct strict inspection on AAC implementation, built up forest police to protect the wildlife inhabitants in forested land, required the industry adopt innovated technology and encouraged the whole society involving in forestry issues. As the return, the forestry enjoyed a positive changes especially the area coverage and volume of forest both increased greatly. It is easy to be impressed that: in recent 20 years, the forestry in China has been making a feature of "Afforestation", "Greening" and "Conservation". It also seems that the echo of "planting" has been reverberating in the whole country's sky. Forest policy has focused on the last reforestation and natural conservation. China inherited a heavily populated, economicundeveloped, ecological-degraded land. It had to and will have to work for a rehabilitated environment.

Although great progress has been made in recent years, China's forestry still meet some dilemma: how to revitalize the forest industries which retreated for resource protection; How to find alternate way replacing the local traditional lifestyles which relying merely on timber logging, hunting, fire-farming; How to identify the local ownership and benefit of forests under the public-owned system; How to draw the local people to join in ecological-improving efforts with little economic interests; How to build up regulations, principles, guidelines, incentives for sufficient and healthy participatory forest management; How to provide the people with easilyunderstandable knowledge, information about our forests and wildlife. Our foresters, professionals, educators, policy makers and legislators face a great deal of challenges to steward our forests for the future generations.

In the early of 1990s, the field of forestry in China accepted the concept of sustainable development and began to conduct key researches about the principles, strategy, criteria and indicators of sustainable forest management. The leading forestry NGOs, scientists, social activists and journalists join the efforts of spreading the idea of sustainability and trying to promote the establishment of healthy, participatory management systems. The government issued Agenda for 21st Century and Forestry Action Plan. The Congress advised the Forests Act, other legislative regulation on environment, water, wildlife conservation has been adopted to protect the natural resources. A lot of small mills for pulp and papermaking, logging, timber sawing will be closed. Cutting in natural forest areas will be limited or forbidden. The right of local people or communities will be enhanced to share the management and employment. Legislative enforcement will be the priority in future forestry development (Xiaoping, 1998).

Several of China's provinces are currently undertaking major reforms to collective forest tenure that will have far-reaching implications for land use distribution, the economic and ecological value of forests, rural livelihoods, and more broadly the character of many parts of rural China. The term "collective forest reform" refers to a general policy that has been emerging since the early 2000s from national sponsored pilots and provincial-level initiatives. At their most basic, these collective forest tenure reforms are designed to improve forest management incentives by transferring forest use rights from village collectives to individual households. Individual households, in turn, have the legal ability to transfer forest use rights, providing a foundation for consolidation of forest resources into larger holdings and, in theory, for improved economic management of forests. As is often the case 
in China, the central government formulated and announced its official policy after the policy had already been initiated and tested at the provincial level. The new national policy was officially publicized by the Cen- tral Committee of the Communist Party of China and the State Council on July 14, 2008 and is entitled "Guidelines on Fully Promoting Collective Forest Tenure System Reform." This reform encourages collective forest owners to reassess and reallocate their forest use rights (not the land itself) based on a majority votea two-thirds vote either by the entire village assembly or the committee of village representatives.

This recent collective forestry tenure reform is regarded as the third Land Reform and has been implemented to accelerate China's rural restructuring. In departing from previous top- down policy changes, the reform has focused on local collective practices and actions. It indicates a shift in China's rural governance, away from direct intervention towards support for local collective actions. While on the surface this collective forest tenure reform process allows for the large- scale commercialization of collectively managed forests, implementation is significantly more complex than this relatively simple caption would suggest. The reforms give decision-making authority on whether and how to allocate collective forests to elected village representatives and any such decisions must be approved by a two-thirds majority of these representatives. Because of the variety of existing collective forest management regimes and preferences for tenure arrangements, during pilot implementation of collective forest tenure reforms a number of different models have emerged both across and within different provinces of China.

\subsection{Institutions, Stakeholders and Public Participation in Sustainable Forest Management}

\subsubsection{South Korea}

South Korean forests consist of national (24\%), local government-owned forests (8\%), and private forests (68\%) (KFS, 2015). According to Article 6 of the Framework Act on Forestry, the state and local governments shall endeavor to cultivate and protect the forests by establishing long-term goals and directions such that various dimensions of forests, such as preservation of the land and the environment and the supply of forest products, may be fully exhibited. According to Article 3 of State Forest Administration and Management, the term "management of state forests" signifies activities that produce forest products, such as lumber through forestry projects within state forests, including afforestation, cultivating forests, production of forest trees, installation of forest administration infrastructure, protection of genetic forestry resources, and so on, and maintaining and increasing the diverse function of forests, such as economic, social, cultural, and environmental functions. The term "administration of state forests" is defined as property administration, such as the conservation, lease, permission for use, exchange, purchase and sale of state forests (M. S. Park \& Lee, 2016).

South Korea has a long history of Songgye as one type of public participation in forest management. "Songgye" is a traditional social institution for forest management by local residents in the late Chosun Dynasty of Korea (nearly 300 years ago) (Chun \& Tak, 2009). Songye has the rules and regulations similar to the contemporary laws of municipal governments. Sanlimgye was organized following the history of Songgye. Toward the end of the 1950s, a total of 21,628 Sanlimyges, consisting of over 2 million members, were established. However, the Sanlimyges were not spontaneously formed by villagers in the process of forest rehabilitation. The government encouraged communities to build Sanlimgyes consisting of forest owners and villagers to protect and plant trees, while governmental resources were limited to rehabilitating wholly denuded forest lands. According to Article 4 of the Provisional Forest Protection Act, enacted in 1951, the Minister of the Ministry of Agriculture and Forestry could organize and de-organize Sanlimgyes and require certain activities from Sanlimgyes in the process of monitoring forest management.

The Korea Forest Service (KFS), established in 1967 as a central governmental agency in the forestry sector, administers and manages state forests. South Korean forest policies have been implemented according to the National Forest Development Plan (NFDP) established by KFS since 1972. NFDPs present forest policy goals and strategies. KFS implemented strong policies for forest rehabilitation from the 1970 s to the 1980 s, based on the $1^{\text {st }}$ NFDP (1972-1978), $2^{\text {nd }}$ NFDP (1979-1987) and $3^{\text {rd }}$ NFDP (1988-1997) (Park, M. S., \& Lee, 2014).

At that time, $68 \%$ of total forests in South Korea were privately owned. KFS provided forestland owners with not only seedlings and fertilizers but also technology transfer and tax benefits to encourage them to restore private forests. Since the 1990s, KFS has focused SFM towards harmony between the environment, economy and society. KFS administers and manages state forests following the principles of SFM. In particular, the $4^{\text {th }}$ NFDP $(1998-2007)$ and $5^{\text {th }}$ NFDP (2008-2017) propose forest management through public participation as a crucial agenda. At 
that time, the conflicts between two interests, forest conservation and urban development emerged. In most conflict cases, civil society consisting of scientists, NGOs and citizens criticized unsound development plans by governments and enterprises and executed conservation movements including campaigns, demonstration, petitions, and so forth (M. S. Park, 2009). In this context, the policy approach of forest administration has shifted from being supplycentric to demand-centric. KFS investigates citizens' demands and preferences for forests, and establishes and implements forest policies to maximize them.

\subsubsection{China}

China's land tenure had developed to a level similar to the early period of capitalistic countries already at the beginning of the 20th century. China used to be a country with long-term land security. Almost all agricultural land and a large part of forest land had been owned by landlords (mountain lords) and some rich peasants for centuries. Prior to the founding of the People's Republic of China, about $80 \%$ of forest land were owned by landlords and rich peasants, while about $5 \%$ were owned by poor subsistence farmers. Some institutions and land market mechanisms for such private ownership had also been developed. Those institutions are the most fundamental basis for socioeconomic development, including forestry (Zhang, 2001).

The People's Republic of China was founded in 1949. Since then, forestry development has suffered from mis-specified institutions. During the political struggles, afforestation measures, more specifically institutions governing the afforestation measures, proved to be ineffective. The land reform of 19491952, and the subsequent socialist transformation, completely destroyed the most basic institutions (property rights) that had been developed for hundreds, even thousands of years. The reforms also broke the rules governing private property rights. In the short term, the land reform did have some positive effects on rural development and equal income distribution, but the long-term negative impact has been significant and far-reaching. Private land and forests were confiscated and redistributed to the public. The once clear boundary between different communities became ambiguous. Forests suffered greatly from such changes and uncertainty (Zhang, 2001).

The Cultural Revolution from 1966 to 1976 to some extent further damaged the former institutions, not only the institutions governing trees and land, but also the institutions governing human rights. Not only were the markets for capital, labour, land and trees prohibited, but so were the markets for ideas. It was also during this time that the informal institutions, such as Buddhist and Taoist temples together with their forests were destroyed. Thus, some exclusive forest land was converted to open access.

Economic reforms in recent decades have produced high and sustained economic growth rates and lifted millions of people out of poverty. Together with economic reforms, concurrent political reforms in China have decentralised many decision-making processes and created new democratic institutions, especially in rural areas. This process has ceded new political powers and established new economic incentives; it has also transferred some naturalresource management powers to local entities (Xu \& Ribot, 2004). The reforms have reintroduced the household as the key unit of production and have placed market demand rather than subsistence concerns at the centre of production decisions. Furthermore, they have introduced moredecentralised decision-making systems that should increase local empowerment.

To manage its extensive forestry resources the government operates a complex hierarchy of administrative institutions. There are five levels of forestry administration under each level of the government administration, including the State Forestry Administration (SFA) (formerly known as the Ministry of Forestry) at the centre, provincial and prefecture/city forestry departments, county forestry bureaux and town and township forestry stations. This hierarchical system of administration fosters an approach to forestry development that follows conventional planning, project formulation and implementation (Liu et al., 2004). The mechanism of stakeholder participation for sustainable forest management can be divided into two levels: First, the national level. For major policies with an impact on the whole country such as desertification control and returning farmland to forest, the Chinese government has established a mechanism of coordination between related ministries and local governments, and opened a policy consultation channel to solicit opinions from various stakeholders, including rural households and forestry workers. Second, direct participation of the private sector in forestry policy-making at county or village level. For example, the proposals for the reform of village-level collective forest tenures must be adopted by the village committee. Moreover, the opinions and suggestions of farmers and forestry workers at the primary level concerning forestry policy implementation are also reflected through the forestry policy monitoring systems established by various departments, including the monitoring system for the implementation of "returning farmland to 
forest" policy established by the National Bureau of Statistics, the monitoring system of the social and economic benefits of major forestry projects led by the State Forestry Administration, and various rural policy monitoring systems supported by research institutions and universities (GoPRC, 2013).

\subsection{Challenges and Lessons learned}

\subsubsection{South Korea}

South Korea successfully implemented the National Reforestation Programme, and restored the forest ecosystem which now occupies $64 \%$ of the country's landscape. During the implementation of the First and Second Plans from 1973 to 1987, un-stocked area decreased by $77 \%$, forest area increased $9 \%$, and total growing stock increased $270 \%$. One could learn the following lessons from the success of the National Reforestation Programme that could be valuable for sustainable forest management and rehabilitation in other nations of the region.

First, the most important factors were the continuous support from the head of the country, and the fact that forest rehabilitation was made the government's top priority. President Park himself led the planning, implementation, and coordination of the Programme. $\mathrm{He}$ transferred the KFS to the MOHA for more effective implementation, and coordinated national finance and administrative power to fully support the Programme. Also, he wove the Programme in with other top priority government projects such as the 5Year Economic Development Plan, Saemaul Undong, and the National Comprehensive Development Plan. Once forest rehabilitation became the top priority government project, national finance could be funneled continuously to the Programme. Additionally, central and regional administrative/technical powers were mobilized for the reforestation, erosion control, and clearing slashand-burn fields. Police forces were mobilized for forest protection. The case of the South Korea suggests that in order for a developing country with low income level to solve forest problems, it requires strong and committed leadership along with efforts to put forest issues in the mainstream.

Second, it is important for the government to diagnose the underlying causes of deforestation, and then to establish a comprehensive plan to address these issues. The Korean government identified direct drivers early on, such as household fuelwood use, illegal logging, and slash-and-burn fields, and understood that the underlying cause for all of these drivers was poverty. The government successfully initiated the 5-Year Economic Development Plan in 1962 to alleviate poverty. With economic growth, fuelwood was no longer the primary energy source for households, and with the rural population migrating to urban areas, pressures on forests causing degradation were decreased. Challenges like the prevention of illegal logging, the clearing of slashand-burn fields, and creation of forest resources were solved through the establishment of the comprehensive Forest Rehabilitation Programme, as well as with the support of administrative, police and technological power led by the country. The successful case of the South Korea shows that even with a low income level and weak governance framework, government efforts can overcome forestry challenges (KFS, 2014).

Third, with clear policy objectives in the background, continuous promotion is needed to bring out the capacity of the citizens. South Korea at the time had been suffering through natural disasters such as drought, flood, and soil loss every year. With the visible growth in the industrial sector, the denuded forests became the top priority of the government. The government announced its quantitative reforestation goal of one million ha within the First Plan, along with its long-term vision of complete reforestation. Due to awareness raising, the nation acknowledged the necessity and supported the government's decision.

The government emphasized and reinforced the ideology that 'planting a tree is an act of patriotism' with the aim of developing a nationwide treeplanting movement. Every year the government chose a targeted area for planting in January and February. Then in March, it started advocating for the needs of forest rehabilitation and forest protection through each ministry by training local populations and promoting through mass media. In other words, the government needs to present clear policy goals and use a systematic publicity strategy to achieve continuous promotion of the Programme over a long period of time to ensure the support and attention of the nation (KFS, 2014).

There were unintended consequences of the 1970 s National Reforestation Programme. 'The Absolute Greening' summed up the reforestation policies of the period perfectly. As the name implies, during the 1970 s, the government and public took the lead in the tree-planting without taking the forest owners preference of tree species into consideration. As a consequence, most forest owners ended up relying on government-led reforestation policies and grants, rather than taking a stance on matters concerning their forests. In later years, establishing cooperative 
governance between the government-led National Reforestation Programme and stakeholders became one of the programme's top priorities. Moreover, the rapid implementation of 'The Absolute Greening' over a short period of time left the government with little time to study the forest ecosystems they were trying to rehabilitate, which led to a mismatch between tree species and the surrounding environment (KFS, 2014).

\subsubsection{China}

Thirty years of economic transformation and institutional reform in China have eliminated some of the institutional barriers to the development of effective community participation in forest management. The shift towards a socialist market economy will require institutions to be- come marketoriented and accountable to their customers, rather than functioning as agencies for the implementation of government policy (Jinlong Liu, 2007). Households, as the basic management and decisionmaking units, are the 'new' customers, rather than recipients of governmental support research and extension organizations. Under the discourses of "development" and "reform", Chinese politics have provided avenues for disseminating the participatory approach, as local governments have competed for the award of pilot development projects by emphasizing participatory approaches that satisfy the needs of farmers (voters). Local governments and communities have learned a great deal from such pilot projects and the benefits of inclusive processes are slowly being realized. Nonetheless, community participation in forest management in China still needs to be driven by the international community through development and technical support programmes (such as the PRC-GEF Partnership on Land Degradation in Dryland Ecosystems) rather than by the internal power of local governments. Significant institutional barriers need to be rectified, such as the clarification of policies that impede the development of NGOs and the removal of government silos that impede effective coordination and communication (Jinlong Liu \& Innes, 2015).

Overall, with a few exceptions (e.g., Li et al., 2009), sustainable forest management has yet to become a mainstream theme in research, development and education in China. A lack of research and experienced practitioners means that there are few professionals who have field experience in social and participatory forest management. When they are trained, academics and professionals with a strong understanding of participatory forest management and field experience are rarely hired by the forest industry; many industry and development professionals have little understanding of the culture or history of forests or of the importance of forests to livelihoods, food security and culture. Several important questions remain unanswered. How is the knowledge and technology of SFM, disseminated at the local level? How can these technologies and knowledge be internalized? What kind of outside support and law are needed for these technologies and knowledge to be accepted and internalized by local communities?

Sustainable forest management today in China has many obstacles to overcome before it will be widely adopted at a national scale. These include:

- Public participation in decision-making for forestry projects and policies needs to include multiple stages, including prior to, during and post-implementation.

- Political parties should not be able to impede public participation. It has been shown that Chinese party-state organizations impeded civil society from adequately participating in the Sino-Germany Afforestation Projects and there are few mechanisms avail- able to involve public society in the forestry policy making and legal reform.

- Staff capacity needs to be improved, as it is low at nearly all levels and local level forestry agencies continue to operate with top-down decision-making despite the need for a bottomup approach.

- The system of forest land ownership remains to be resolved, as forestry continues to suffer from a disproportionate burden of taxation and inappropriate management policies (Liu and Yuan 2010).

Governance in China has to succeed in managing social welfare alongside environmental and economic issues. Davies \& Wismer (2007) revealed that the government was unable to implement sustainable forestry adequately whilst balancing short- and longterm development goals. Unfortunately, in this case and in others, forestry goals have been targeted at either conservation purposes or material production, and achieving a sustainable balance between the two has proven elusive. Despite these difficulties, sustainable forestry management shows enormous potential, especially when considering its short period of development and the limited knowledge and technologies that have been generated to date.

\section{Conclusions and Way Forward}

Nearly $55 \%$ of the world's forests and more than $80 \%$ of the world's population are in the stage of development where forests are a critical source of 
income, food and other products and often are critical to the very survival of the communities. The significance of forests and associated ecological systems in northeast Asia has become apparent in recent years. In the current direction of economic development, international attention has been increasingly drawn to temperate and boreal forests, which account for slightly less than half of the world's forests. In northeast Asian regions, including the Korean Peninsula, China, Mongolia and the Russian Far East, threats to temperate and boreal forests are immense.

For the next century, forest resources will be a key component in the establishment of a vigorous and sustainable economy and way of life. They have direct and indirect economic, environmental, political, social and cultural impacts far beyond the boundaries of a single region, province or nation. Therefore, it is critical that the international community seeks to improve inter-relationships to ensure access to accurate and timely information in order to manage forestry in a sustainable way and clearly identify the condition of forests and their contributions to global environmental stability. Collaboration is needed to stop desertification and concentrate efforts on rehabilitation works through planting trees.

In the northeast Asian region, the major emphasis of international collaboration will be on restoration of desert areas and degraded forest ecosystems. Although many of the forests in the northern temperate and boreal forests have been deforested and degraded, possibilities exist in the broad areas of reforestation, multi-purpose forest management, conservation of biological diversity, integrating land use, utilization of marginal agricultural lands and generation of related business and trade. To undertake these activities, we should form partnerships and organize regional consultations at national and international levels. Moreover, we need to strengthen participatory and advocacy mechanisms to organize awareness-raising campaigns on environmental conditions and to mobilize media to increase public awareness. It is necessary to promote the improvement of capacity, by preparing local models and providing training through workshops and seminars, assist in strengthening the capacity of community groups, and translate programs and plans into local languages.

The forest rehabilitation programs implemented in both South Korea and China in the recent past made a very significant contribution to the increase in forest coverage, soil erosion control, carbon sequestration, clean water supply, healthy hydrological environment, wood supply, biodiversity protection. The successful efforts towards large scale afforestation and forest restoration in both countries indicate the respective government's commitment to social and private investment, strong governance and regulation policies. However, literature suggests the quality of established forests is still rather low compared to the natural forests to maintain their ecological and environmental services and productivity. The shift from large-scale tree planting to sustainable management of forest resources and forest land- scape rehabilitation will drive the forestry investment from afforestation to forest rehabilitation.

Equally critical is the role of the forest rehabilitation in initiating sustainable forest management. With restored forest ecosystems, the volume of forest resources grows, and so does the quality of life for wildlife species and humans that rely on forests for their livelihood. Moreover, the success also had positive effects on biodiversity and securing forest water resources. Forests not only offer ample economic opportunities for people, but provide them with recreational services. The more a society and its economy develop, the more forests become a part of popular culture. These are only examples of the benefits which are provided by forests. In other words, the successful implementation of the Plans was a significant stepping stone for sustainable forest management, allowing forests to function ecologically, economically, socially, and culturally.

Thanks to National Reforestation Programme, the South Korea achieved successful forest transition. Over time, lost forest fully recovered, and volume grew. In the 1950s, Korean forest coverage hit its lowest, marking up only $35 \%$ of the landscape. From that point on, forest coverage only increased, and is currently managed to stay proportionately higher than China, and other North-East Asian countries such as Mongolia and Democratic People's Republic of Korea (or North Korea). The South Korea is not however the only such success story. Western countries including USA and New Zealand also successfully restored their lost forests. However, considering countries with less than $10 \%$ forest cover like China, the Korea's case is certainly impressive. No account of Korea's success in forest restoration would be complete without highlighting the role of government leadership. Its experience has provided useful insights to neighbouring countries such as China, which carried out similar forest transition projects in the latter part of the $20^{\text {th }}$ century.

The Chinese forest rehabilitation programs implemented in the recent past made a very significant contribution to the increase in forest 
coverage, soil erosion control, carbon sequestration, clean water supply, healthy hydrological environment, wood supply, biodiversity protection. The successful effort of large scale afforestation in China indicates the government's commitment to social and private investment, strong governance and regulation policies. However, the quality of established forests is still rather low to maintain their ecological and environmental services and productivity. The shift from large-scale tree planting to sustainable management of forest resources and forest land- scape rehabilitation will drive the forestry investment from government afforestation to forest rehabilitation. Essential measures to ensure continuous improvement of Chinese forest resources and forest functions include logging quotas according to the forest ecosystem productivity, reduction in the forest tax for commercial forests, increase in the compensation for ecological forests, reform of the forest tenure arrangements for collective forests, increase in the government budget for sustainable forest management, and formulation of sustainable forest management plans. These support measures are even more important given China's fast growing economy and the associated threats to the health and survival of its environment.

In conclusion, after the formation of PRC and the completion of the Korean War, both South Korea and China made efforts to overcome severe deforestation and forest degradation. South Korea achieved forest restoration completely, while China has is now very close to completely reverse the trends of forest loss across its vast geographic area. This paper examined the trends and features of forest management in South Korea and China, especially with reference to forest cover rehabilitation and sustainable forest management. Both countries have different forest policy designs and forest governance structures. There are significant differences in their legal systems. The order of normative effects in South Korea is as follows: constitutional laws, laws, decrees and regulations. On the other hand, Chinese order of normative effects allows Communist Party regulations, constitutional laws, by-laws and Cabinet guidelines. Nevertheless, China's complete legal system, strict legislation and powerful law enforcement in recent years have contributed to establish a sound forest governance system and play a crucial that guarantees sustainable forest management in recent future. Furthermore, through the collective forest reform and practices of clarification of property rights and contracting forests to households, the Chinese government arouses enthusiasm for smallholders to participate in forest management, establishing a local system for attaining sustainable forest management in collective forest zones, which accounts for a half of the national forest area. The results from the analysed literature indicate meaningful lessons for policy design to avoid deforestation and forest degradation and promote sustainable forest management in South Korea and China, and other developing countries in the NorthEast Asia.

\section{References}

1. Arrow, K. (1996). Rights to nature: ecological, economic, cultural, and political principles of institutions for the environment. Island Press.

2. Bae, J. S., Joo, R. W., \& Kim, Y.-S. (2012). Forest transition in South Korea: reality, path and drivers. Land Use Policy, 29(1), 198-207.

3. Barrow, E., \& Murphree, M. (2001). Community conservation: from concept to practice. African Wildlife and Livelihoods: The Promise and Performance of Community Conservation, 24-37.

4. Carle, J., Vuorinen, P., \& Del Lungo, A. (2002). Status and trends in global forest plantation development. Forest Products Journal, 52(7/8), 12-23.

5. Chun, Y. W., \& Tak, K.-I. (2009). Songgye, a traditional knowledge system for sustainable forest management in Choson Dynasty of Korea. Forest Ecology and Management, 257(10), 2022-2026.

6. Davies, E. G., \& Wismer, S. K. (2007). Sustainable forestry and local people: The case of Hainan's Li minority. Human Ecology, 35(4), 415-426.

7. Dietz, T., Ostrom, E., \& Stern, P. C. (2003). The struggle to govern the commons. Science, 302(5652), 1907-1912.

8. Fang, J., Chen, A., Peng, C., Zhao, S., \& Ci, L. (2001). Changes in forest biomass carbon storage in China between 1949 and 1998. Science, 292(5525), 2320-2322.

9. FAO. (2000). State of the World's Forests 1999. Rome, Italy: Food and Agricultural Organization of the United Nations (FAO).

10. Holvoet, B., \& Muys, B. (2004). Sustainable forest management worldwide: a comparative assessment of standards. International Forestry Review, 6(2), 99-122.

11. KFS. (2014). Lessons learned from the Republic of Korea's National Reforestation Program (p. 50). Daejeon, South Korea: Korea Forest Service (KFS).

12. KFS. (2015). 2015 Statistical Yearbook of Forestry. Daejeon, Korea: Korea Forest Service (KFS).

13. Kim, B., Kwon, G., Park, G., Park, M., Park, H., Bae, I., ... Lee, S. (2009). Analysis of Korean Successful Case of Reforestation. Daejeon, South Korea: Korea Forest Service.

14. Kleine, M., \& Lee, D. K. (2007). Rehabilitation of Degraded Forest Lands in Northeast Asia - A Synthesis. In D. K. Lee (Ed.), Keep Asia Green Volume II "Northeast Asia" (Vol. 2, pp. 7-15). IUFRO Sectreteriat, Vienna, Austria: International Union of Forest Research Organizations (IUFRO).

15. Koo, J.-C., Park, M. S., \& Youn, Y.-C. (2013). Preferences of urban dwellers on urban forest recreational services in South Korea. Urban Forestry \& Urban Greening, 12(2), 200-210.

16. Lee, D. K., Bae, J., Shin, J., Park, P., Park, Y., \& Lee, K. (2010). Korean forests: lessons learned from stories of success and failure. Seoul, South Korea: Korea Forest Research Institute.

17. Lee, D. K., \& Lee, Y. K. (2005). Roles of Saemaul Undong in reforestation and NGO activities for sustainable forest management in Korea. Journal of Sustainable Forestry, 20(4), 1-16.

18. Li, J., Tuo, H., \& Liu, X. (2009). On the factors influencing the Participatory Forest Management in rural communities in the west of China (Vol. 2, pp. 255-261). Presented at the 
Proceedings of 2009 International Conference on Public Administration (5th).

19. Liu, J, \& Innes, J. (2015). Participatory Forest Management in China: key challenges and ways forward. International Forestry Review, 17(4), 477-484.

20. Liu, Jinlong, Wu, J., Yuan, J., \& Zhou, P. (2004). Enhancing community participation: participatory forestry management in China. Plummer, J. \& J. Taylor (Eds.), Community Participation in China: Issues and Processes for Capacity Building, 93-138.

21. Liu, Jinlong. (2007). Contextualizing forestry discourses and normative framework towards sustainable forest management on contemporary China. International Forestry Review, 9(2), 653-660.

22. Moon, K. H., \& Park, D. K. (2004). The role and activities of NGOs in reforestation in the northeast Asian region. Forest Ecology and Management, 201(1), 75-81.

23. Noronha, R. (1981). Why is it so difficult to grow fuelwood. Unasylva, 33(131), 4-12.

24. Park, M. S. (2009). Media discourse in forest communication: the issue of forest conservation in the Korean and global media. Cuvillier.

25. Park, M. S., \& Lee, H. (2014). Forest policy and law for sustainability within the Korean Peninsula. Sustainability, 6(8), 5162-5186.

26. Park, M. S., \& Lee, H. (2016). Legal opportunities for public participation in forest management in the Republic of Korea. Sustainability, 8(4), 369.
27. Park, M. S., \& Youn, Y.-C. (2013). Development of urban forest policy-making toward governance in the Republic of Korea. Urban Forestry \& Urban Greening, 12(3), 273-281.

28. Park, M., \& Youn, Y. (2013). Policy integration for reforestation in the Republic of Korea (Vol. 2123, p. 8689). Presented at the Proceeding of the International Symposium on Transition to Sustainable Forest Management and Rehabilitation: The Enabling Environment and Roadmap, Beijing, China

29. Piao, S., Fang, J., Ciais, P., Peylin, P., Huang, Y., Sitch, S. \& Wang, T. (2009). The carbon balance of terrestrial ecosystems in China. Nature, 458(7241), 1009.

30. Shi, L., Zhao, S., Tang, Z., \& Fang, J. (2011). The changes in China's forests: An analysis using the forest identity. PLoS One, 6(6), e20778.

31. Xiaoping, L. (1998). Forest Policy in China: the Past, Present and Future (pp. 134-147). Presented at the IGES International Workshop on Forest Conservation Strategies for the Asia and Pacific Region 2123 July, 1998, Hayama, Kanagawa, Japan: Institute for Global Environmental Strategies.

32. Xu, J., \& Ribot, J. C. (2004). Decentralisation and accountability in forest management: a case from Yunnan, Southwest China. The European Journal of Development Research, 16(1), 153-173.

33. Zhang, Y. (2001). Institutions in forest management: special reference to China. In World Forests, Markets and Policies (pp. 353-364). Springer. 